\title{
Nonprimary Cytomegalovirus Fetal Infection
}

\section{Infeção fetal não primária por citomegalovírus}

\author{
Sofia Rodrigues ${ }^{1}$ Daniela Gonçalves ${ }^{1}$ Ricardo Taipa ${ }^{2}$ Maria do Céu Rodrigues ${ }^{1}$
}

1 Gynecology and Obstetric Service, Centro Materno Infantil do Norte, Centro Hospitalar do Porto, Porto, Portugal

2 Pathological Anatomy Service, Centro Materno Infantil do Norte, Centro Hospitalar do Porto, Porto, Portugal

Address for correspondence Sofia Pina Rodrigues, MD, Centro Hospitalar do Porto, Largo Prof. Abel Salazar, 4099-001, Porto, Rev Bras Ginecol Obstet 2016;38:196-200.

\section{Abstract \\ Keywords \\ - cytomegalovirus fetal infection \\ - nonprimary infection \\ - lissencephaly}

\section{Resumo}

\section{Palavras-chave}

- infeção fetal por citomegalovírus

- infeção não primária

- lisencefalia
Cytomegalovirus (CMV) is the most common congenital viral infection, causing hearing, visual and psychomotor impairment. Preexisting maternal CMV immunity substantially reduces, but not eliminates, the risk of fetal infection and affectation. This article is about a case of nonprimary maternal CMV infection during pregnancy, with vertical transmission, resulting in severe fetal affectation. Preconceptional analysis indicated maternal CMV past infection. Pregnancy progressed uneventfully until the 20th week ultrasound (US), which revealed cerebral abnormalities: thin and hyperechogenic cerebral cortex with prominent lateral ventricles, bilateral periventricular hyperechogenicities, cerebellar vermis hypoplasia and absent corpus callosum. The MRI suggested these findings were compatible with congenital infection rather than primary brain malformation.

The fetal karyotype was normal. The title of CMV's IgG antibodies almost tripled. Since the first semester, analysis of the polymerase chain reaction (PCR) for CMV DNA in the amniotic fluid was negative. The pregnancy was terminated at 23 weeks. Neuropathological findings at autopsy showed severe brain lesions associated with CMV infection.

O citomegalovírus (CMV) é a infeção viral congénita que mais comumente causa deficiência auditiva, visual e psicomotora. A preexistência de imunidade materna reduz substancialmente, mas não elimina, o risco de infeção e afetação fetal. Trata-se de um caso de infeção materna não primária por CMV durante a gravidez, com transmissão vertical, resultando em afetação fetal severa. As análises preconcepção indicavam infecção passada por CMV. A gravidez decorreu sem intercorrências até a ecografia efetuada na 20a semana, que revelou alterações cerebrais: córtex cerebral fino e hiperecogénico com ventrículos laterais proeminentes, hiperecogenecidades periventriculares bilaterais, hipoplasia do vérmis cerebeloso e ausência de corpo caloso. A ressonância magnética sugeriu que estes achados eram mais favoráveis a uma infeção congénita do que com uma malformação cerebral primária. O cariótipo fetal era normal. O título de anticorpos IgG para CMV havia triplicado desde a dosagem do primeiro trimestre. O PCR para o DNA do CMV no líquido amniótico foi negativo. A gravidez foi interrompida na 23a semana. Os achados neuropatológicos na autópsia mostraram lesões cerebrais severas associadas a infeção por CMV. received

September 2, 2015

accepted

January 11, 2016
DOI http://dx.doi.org/

$10.1055 / \mathrm{s}-0036-1583170$. ISSN 0100-7203.
Copyright $\odot 2016$ by Thieme Publicações License terms Ltda, Rio de Janeiro, Brazil

(®) $\ominus \circledast$ 


\section{Introduction}

Cytomegalovirus (CMV) is the most common congenital viral infection, with a birth prevalence of 0,2 to $2,2 \%,{ }^{1}$ causing hearing and visual impairment and delay of psychomotor development. ${ }^{1}$

Primary CMV infection during pregnancy has an incidence of 1 to $4 \%{ }^{2}$ and the global risk of transplacental infection is $\sim 40 \%{ }^{3,4}$ The risk of fetal infection increases with the gestational age $\mathrm{e}^{1,2,5}$ (according to a study involving 508 pregnancies, vertical CMV transmission rate by gestational age at the time of maternal infection was $0 \%$ in the pregestation group, $4.6 \%$ in the periconception group, 34.8 , 42 and $58.6 \%$ respectively in the first, second and third trimester groups). ${ }^{3}$ Severe disease may affect fetuses infected during the first trimester as well as the second, but rarely affects fetuses infected later on in pregnancy. ${ }^{3,5}$ Also, congenital infection impairs placental development and functions, and should be considered as an underlying cause of intrauterine growth restriction (IUGR), regardless of virus transmission to the fetus. ${ }^{6}$

Ten to $15 \%$ of congenitally infected newborns are overtly symptomatic at birth and will present neurodevelopmental damage within the first three years. ${ }^{1}$ From those, 20 to $30 \%$ die, mostly of disseminated intravascular coagulation, hepatic dysfunction, or bacterial superinfection; severe neurologic morbidity occurs in 50 to $60 \%$ of survivors. ${ }^{1,5,7}$ of the asymptomatic infants at birth (85 to $90 \%$ ), 5 to $15 \%$ will develop longterm neurodevelopmental morbidity, such as sensorial hearing loss, delay of psychomotor development and visual impairment. ${ }^{1}$

The criteria necessary to recommend universal screening for CMV infection in pregnant women haven't yet been met, and are not recommended by the Centers for Disease Control and Prevention or the American College of Obstetricians and Gynecologists. ${ }^{2,8}$ Prenatal diagnosis is mainly performed when US abnormalities are observed. ${ }^{4}$

Nonprimary maternal CMV infection (reactivation or reinfection with a different strain) occurs more rarely, with less probability of fetal infection (1,5\% in a study with 543 cases of suspected maternal nonprimary infection $)^{9}$ and only 0.2 to $2 \%$ of newborns will develop a symptomatic disease, ${ }^{6}$ which indicates a minor fetal affectation in these cases.

This case draws attention to the gravity of a nonprimary CMV infection.

\section{Case Description}

The patient is 37 years old, with irrelevant personal and family medical histories, and in her fourth spontaneous pregnancy. The patient has a history of two spontaneous abortions and a term vaginal delivery, which resulted in a healthy child. The spouse is healthy; the couple is not consanguineous.

Preconceptional analysis indicated maternal immunity to Rubella, Toxoplasmosis and CMV. First trimester routine analysis at the 11th week of pregnancy indicated CMV IgG and IgM of respectively $848.9 \mathrm{Ul} / \mathrm{mL}$ (positive threshold $\geq 1$ ) and $0.379 \mathrm{Ul} /$
$\mathrm{mL}$ (negative threshold $<0,8$ ). The first trimester US did not show fetal anomalies, and the combined prenatal screening for chromosomal abnormalities was negative.

At 20 weeks of gestation, US revealed cerebral abnormalities: thin and hyperechogenic cerebral cortex with prominent lateral ventricles, bilateral periventricular hyperechogenicities, cerebellar vermis hypoplasia and absent corpus callosum (-Fig. 1). Amniocentesis was performed and the karyotype was normal (46, XY).

An extended serology study was then performed, and it showed no immunity to Herpes simplex virus type 2 and immunity to Toxoplasmosis, Herpes simplex virus type 1, Parvovirus and CMV. However, CMV IgG title increased almost three times since the first trimester analysis, and CMV IgM kept negative (IgG $2695.0 \mathrm{Ul} / \mathrm{mL}$ and $\operatorname{IgM} 0.333 \mathrm{Ul} / \mathrm{mL}$ ) - these serologic tests were performed in the same laboratory as the first trimester tests. IgG avidity testing was high.

When asked about flu-like symptoms, the patient mentions an episode during the second trimester of pregnancy; however, as it was mild, it was difficult to precise the time of it.

Magnetic resonance imaging (MRI) at 22 weeks of gestation confirmed US findings and raised the hypothesis of
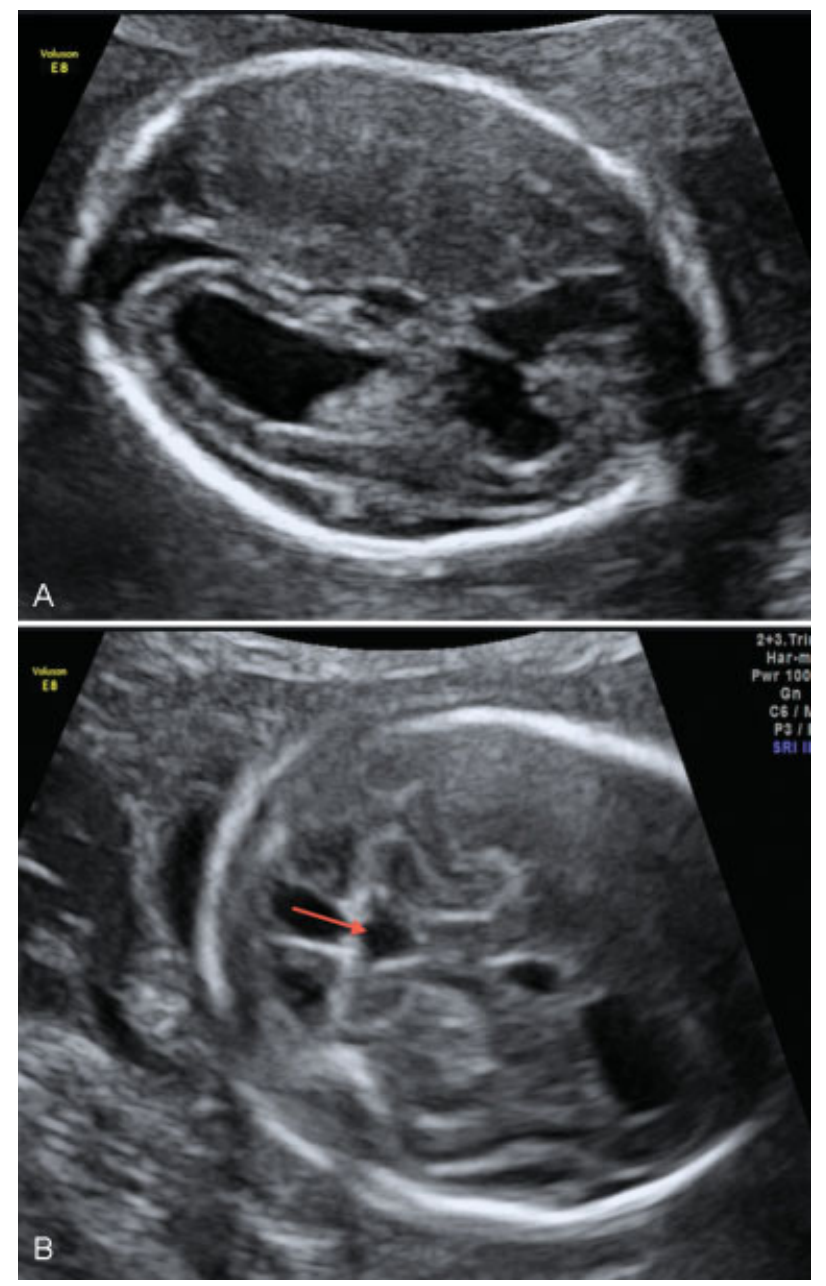

Fig. 1 (A) Ultrasound at 20 weeks of gestation - thin and hyperechogenic cerebral cortex with prominent lateral ventricles and bilateral periventricular hyperechogenicities. (B) Ultrasound at 20 weeks of gestation - cerebellar vermis hypoplasia (arrow). 


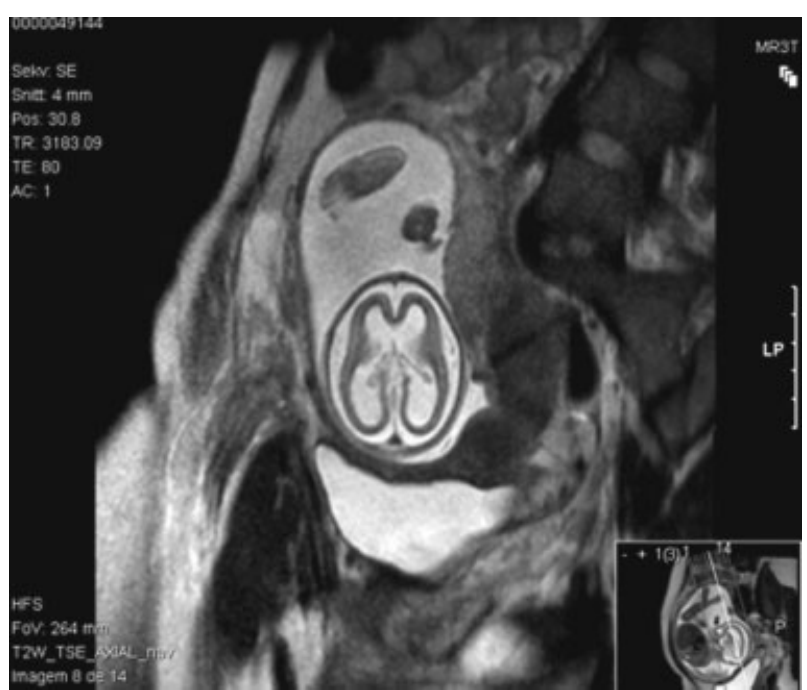

Fig. 2 Magnetic resonance imaging at 22 weeks of gestation with lissencephalic appearance.

fetal infection: " $[\ldots]$ enlargement of the cerebrospinal fluid circulation spaces at the expense of marked reduction in the thickness of the cerebral parenchyma of both hemispheres of lissencephalic appearance [...] suggesting serious sequelae of brain infection (group TORCH? other?) rather than primary malformative injury of the central nervous system" (-Fig. 2).

\section{Outcome and Follow-up}

The pregnancy was terminated at 23 weeks.

At this time, a new sample of amniotic fluid was collected to perform PCR for CMV DNA. The result was negative. Pathologic examination study of fetal and placental tissues revealed cerebral ventricular dilation with

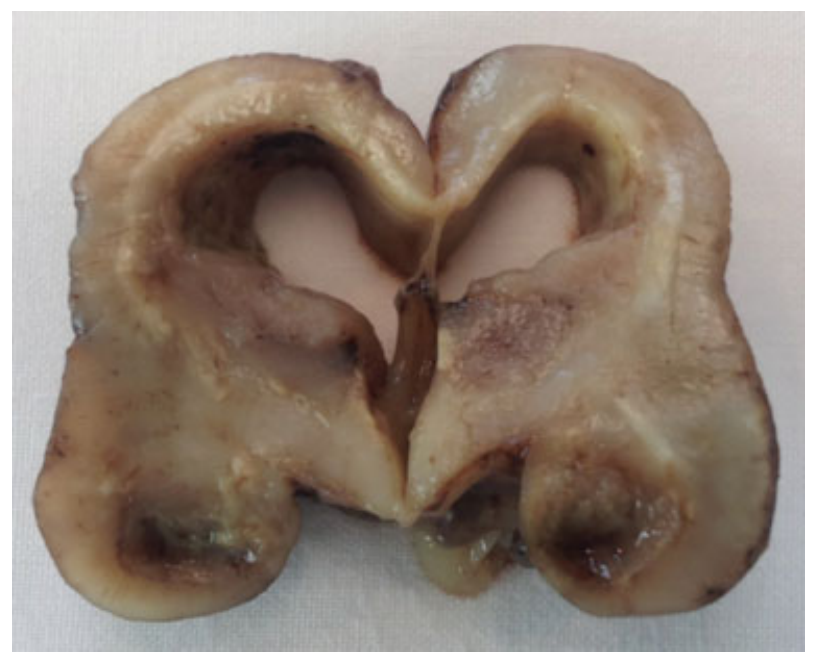

Fig. 3 Macroscopical findings - coronal section at the level of the hippocampus showing dilation of lateral ventricles, extensive white matter periventricular lesions with focal necro-hemorrhagic lesions at this level and also at the level of the amygdala/hippocampus and thalamus. necro-hemorrhagic and calcified periventricular lesions, necro-hemorrhagic lesions also at the level of the basal ganglia, hippocampus, periventricular regions of brainstem and cerebellar hemispheres. There were areas of four-layer polymicrogyria and frequent cellular viral inclusions (cytomegalic cells), particularly in the germinal matrix and near the necrotic lesions. These cells tested positive for CMV immunohistochemistry (-Figs. 3, 4 and 5). Immunohistochemical detection of CMV DNA was found not only in the fetus brain, but also in his liver, heart and in the placenta.

\section{Discussion}

All the investigation and outcomes in this case suggest a probable CMV secondary infection, which can be due to a reactivation or reinfection with a different strain. According to the maternal serology and the morphologic US performed, the maternal CMV secondary infection must have occurred between 11 and 20 weeks of pregnancy.

The preferred approach for diagnosing fetal infection is PCR testing for DNA virus in the amniotic fluid, ${ }^{1,3,4}$ which has a sensitivity of $75-100 \%{ }^{4}$ Gestational age at amniocentesis and the time elapsed since the suspicion of infection are critical factors for the sensitivity of the method. ${ }^{1,3,4}$

The PCR for CMV DNA negative result was indeed a false negative. Although this method is recognized as the gold standard for prenatal diagnosis of fetal CMV infection, the gestational age and the time lag between maternal infection and amniocentesis is a critical factor influencing sensitivity. To achieve the highest sensitivity, amniocentesis should be performed after 21 weeks of gestation and at least 6 to 7 weeks after the onset of maternal infection reflecting the time it takes for placental infection, transmission to the fetus, viral replication in the fetal kidney, and excretion into amniotic fluid. ${ }^{1,3,8}$ In spite of having fulfilled the first prerequisite, the time lag might not have been achieved. Nevertheless, we were reaching the legal limit for terminating the pregnancy, and even without a prenatal diagnosis, the US findings foretold a poor outcome for the offspring.

The idea that nonprimary CMV maternal infection will not result in severe fetal sequelae and congenital disease has been proved different in several published cases. ${ }^{5,10,11}$ The preexisting maternal CMV seropositivity substantially reduces, but not eliminates, the risk of fetal infection and affectation; therefore, the use of prenatal invasive methods for the detection of fetal infection in nonprimary maternal infections may be justified.

Neurons migrate from the areas where they are born to the areas where they will settle into their proper neural circuits. Neuronal migration starts in the second month of gestation and is controlled by a complex assortment of chemical guides and signals. When these signals are absent or incorrect, neurons do not end up where they belong, resulting in a primary malformative injury called lissencephaly. The lack of gyral development after a defective neuronal migration in the developing brain can be associated with 


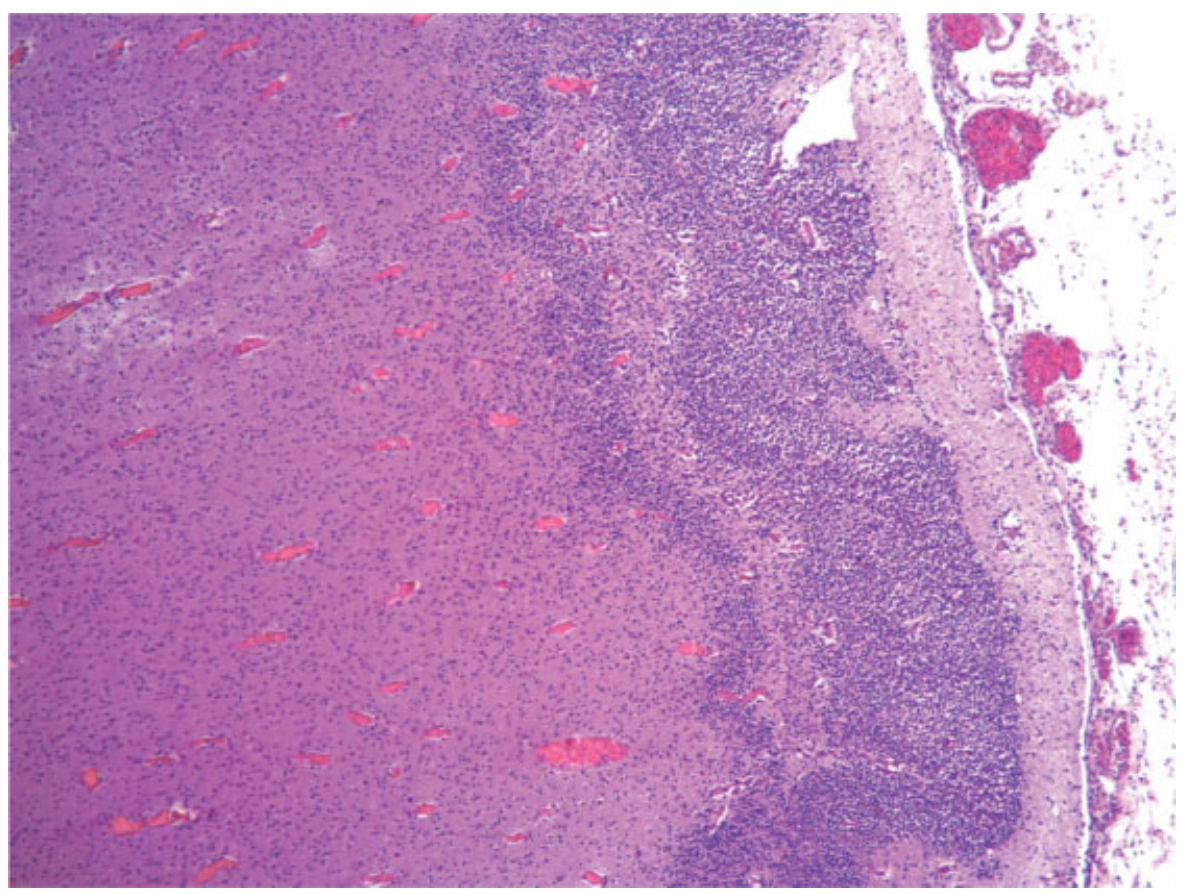

Fig. 4 Histopathological findings showing four-layer polymicrogyria (HE). Magnification, 50x.

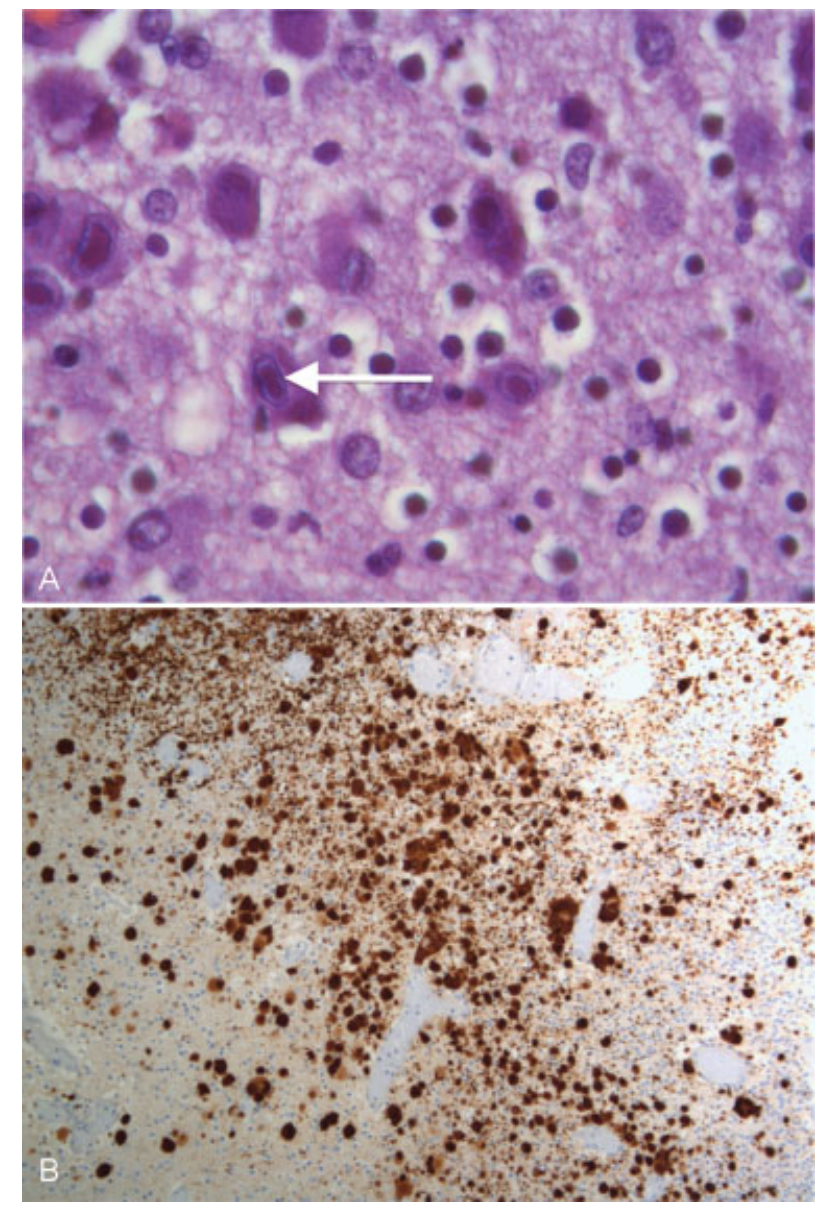

Fig. 5 (A) Histopathological findings - neurons of germinal matrix with some viral inclusions (arrow), with the typical aspect of cytomegalic cells (HE). Magnification, 630x. (B) Histopathological findings - cells positive for CMV immunohistochemistry (some showing colocation with the viral inclusions). Magnification, 100x. the agenesis of the corpus callosum or cerebellar hypoplasia, and is also due to some genetic syndromes. ${ }^{12}$

Neuropathological studies of brains infected prenatally by CMV show evidence of lissencephaly, polymicrogyria, cerebellar hypoplasia and ventricular dilation in consequence of loss of volume (atrophy), ${ }^{7,12}$ findings suggestive of the severity and risk of neurological and motor sequelae. Still, a normal US examination cannot exclude neonatal or long-term morbidity. ${ }^{1,13}$ Mild ventriculomegaly, cerebellar vermis hypoplasia and lissencephaly can also be associated with extra central nervous system abnormalities, chromosomal aberration and other fetal infections like rubella and toxoplasmosis. ${ }^{13}$ In this case, no other abnormalities were found beyond the fetal central nervous system; the karyotype was normal and the other fetal infections were excluded.

There is insufficient evidence to support the use of passive immunization to prevent congenital infection, ${ }^{2}$ and the only known means of reducing the risk of congenital CMV is by reducing exposure to the virus through hygiene measures. ${ }^{2,5}$

Therapies for treatment of congenital CMV are in the experimental stage. In an uncontrolled study published in 2005, administration of CMV-specific hyperimmune globulin to pregnant women with primary CMV infection significantly reduced the rate of intrauterine transmission, from 40 to $16 \%{ }^{14}$ A 2014 randomized placebo-controlled phase 2 trial of virus-specific hyperimmune globulin for the prevention of congenital CMV infection, involving 124 women with primary CMV infection from 5 to 26 weeks of gestation, showed that the treatment with hyperimmune globulin did not significantly modify the course of primary CMV infection during pregnancy. ${ }^{15}$ Other phase 3 studies are under way to further our understanding of the efficacy and safety of 
hyperimmune globulin administration as a means of preventing congenital CMV infection.

Although it is still not recommended, our institution offers pregnant women systematic screening for CMV infection, as well as education about hygienic measures. However, we do not provide any therapy for pregnant women with suspicious or confirmed CMV primary or nonprimary infections.

Nevertheless, the US and MRI findings in this case suggested the presence of severe advanced disease and high risk of long-term neurodevelopmental impairment, so the option of pregnancy termination was obviously raised.

This article is about a rare case of nonprimary maternal CMV infection during pregnancy, with vertical transmission, resulting in severe fetal affectation. The preexisting maternal CMV seropositivity substantially reduces, but not eliminates, the risk of fetal infection and affectation. This article highlights the importance of clinical suspicion and the difficulty of prenatal confirmation of a CMV infection.

\section{References}

1 Yinon Y, Farine D, Yudin MH, et al; Fetal Medicine Committee, Society of Obstetricians and Gynaecologists of Canada. Cytomegalovirus infection in pregnancy. J Obstet Gynaecol Can 2010;32(4):348-354

2 Johnson J, Anderson B. Screening, prevention, and treatment of congenital cytomegalovirus. Obstet Gynecol Clin North Am 2014; 41(4):593-599

3 Feldman B, Yinon Y, Tepperberg Oikawa M, Yoeli R, Schiff E, Lipitz S. Pregestational, periconceptional, and gestational primary maternal cytomegalovirus infection: prenatal diagnosis in 508 pregnancies. Am J Obstet Gynecol 2011;205(4):342.e1-342.e6

4 Picone O, Vauloup-Fellous C, Cordier AG, et al. A series of 238 cytomegalovirus primary infections during pregnancy: description and outcome. Prenat Diagn 2013;33(8):751-758
5 Benoist G, Leruez-Ville M, Magny JF, Jacquemard F, Salomon LJ, Ville Y. Management of pregnancies with confirmed cytomegalovirus fetal infection. Fetal Diagn Ther 2013;33(4): 203-214

6 Pereira L, Petitt M, Fong A, et al. Intrauterine growth restriction caused by underlying congenital cytomegalovirus infection. J Infect Dis 2014;209(10):1573-1584

7 Ornoy A, Diav-Citrin O. Fetal effects of primary and secondary cytomegalovirus infection in pregnancy. Reprod Toxicol 2006; 21(4):399-409

8 Walker SP, Palma-Dias R, Wood EM, Shekleton P, Giles ML. Cytomegalovirus in pregnancy: to screen or not to screen. BMC Pregnancy Childbirth 2013;13:96

9 Yoeli-Ullman R, Lipitz S, Schiff E, Feldman B. 216: Prenatal diagnosis of fetal cytomegalovirus infection in 543 cases of suspected maternal non-primary infection. Am J Obstet Gynecol 2007;197(6, Suppl)S71

10 Boppana SB, Fowler KB, Britt WJ, Stagno S, Pass RF. Symptomatic congenital cytomegalovirus infection in infants born to mothers with preexisting immunity to cytomegalovirus. Pediatrics 1999; 104(1 Pt 1):55-60

11 Stagno S, Pass RF, Dworsky ME, et al. Congenital cytomegalovirus infection: The relative importance of primary and recurrent maternal infection. N Engl J Med 1982;306(16):945-949

12 Cheeran MC, Lokensgard JR, Schleiss MR. Neuropathogenesis of congenital cytomegalovirus infection: disease mechanisms and prospects for intervention. Clin Microbiol Rev 2009;22(1): 99-126

13 Picone O, Teissier N, Cordier AG, et al. Detailed in utero ultrasound description of 30 cases of congenital cytomegalovirus infection. Prenat Diagn 2014;34(6):518-524

14 Nigro G, Adler SP, La Torre R, Best AM; Congenital Cytomegalovirus Collaborating Group. Passive immunization during pregnancy for congenital cytomegalovirus infection. N Engl J Med 2005; 353(13):1350-1362

15 Revello MG, Lazzarotto T, Guerra B, et al; CHIP Study Group. A randomized trial of hyperimmune globulin to prevent congenital cytomegalovirus. N Engl J Med 2014;370(14):1316-1326 